\title{
原著 VII
}

\section{イヌを用いた下㢉における大腸運動に 関する実験的検討}

\author{
順天堂大学外科学第 1 \\ 落合匠長浜徴赨原宣
}

下㾰の際の大腸運動を解明するため，雑種成犬を対象に実験を行った，実験的に下症が認められる動物実 験モデル（全幹迷走神経切離，拘束ストレス負荷）をもちいて各種下痢における大腸運動について経時的 $\mathrm{X}$ 線撮影と strain gauge force transducer 法を用いて大腸運動を記録，検討し以下の結果を得た. 下疬の際， 正常の大腸分節運動の低下が認められ, giant migrating contraction (GMC) が頿回に認められた.これは下 痢の原因のいかんにかかわらず下涠をきたしたすべてに認められた，従来よりいわれている下麻の際の大晹

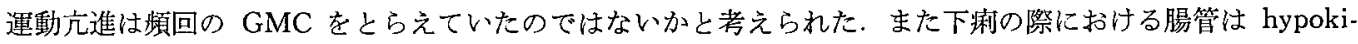
netic ではあるが，一方では頻回に GMC が発生する hypersensitive で hyperreactive な状態にあると考 えられた.

索引用語 : 下峲, 大腸運動, giant migrating contraction, CNS-ENS link

\section{緒容}

下痢の発生機序として，吸収されない物質が消化管内 に存在寸ることによる浸透圧性の下摔を除き，多くの場 合消化管運動の元進により消化管内容物の移送速度が速 くなり，てのため消化管上皮と接する時間が短く，消化 管内容物が十分吸収されえないためであると考えられて きた1〉.しかし，最近大半の下痢はむしろ電解質の吸収 障害, 分泌穴進に起因するものであり, 輸送運動の元 進，ひいて注通過時間の短縮がおこるのは，液体の蓄櫝 による二次的なものであるといわれている，また腸内容 が液体の場合に通過時間の短縮がおこるのは，輸送運動 の増加よりはむしろ分節運動 (segmenting activity) の 低下が主要因であると考えられるようになってきだ2,3. しかしながら，下疮の際におこる大腸運動パターンに関 してはいまだ十分な解明がなされていないのが現状であ z.

今回実験的に種々の下梸の際の大腸運動について経時 的 $\mathrm{X}$ 線撮影と strain gauge force transducer (transducer）を用いて大腸運動を記録，検討し新たなる知見を 得たので報告する。

\section{I. 実験方法}

対象
対象は体重 $15 \mathrm{~kg}$ 前後の雑種成犬 20 頭である，20頭を 下記のごとく 3 群に分けた。

1. 無処置群 10 頭.

2. 全幹迷走神経切離術施行群 (TV 群) 5 頭.

3. 拘束ストレス負荷群（ストレス群） 5 頭.

全幹迷走神経切離術 (TV)

pentobarbital-Na $30 \mathrm{mg} / \mathrm{kg}$ 表静脈内投与後，左第 7 ないし第 8 肋間開胸で前後迷走神経をそれぞれ約 $2 \mathrm{~cm}$ 切除して IV 群をつくった. 観察後 pentobarbital-Na $75 \mathrm{mg} / \mathrm{kg}$ を静脈内投与し屠殺後犠牲解剖を行い神経再 生による再支配のないことを確認した。

拘束ストレス負荷

ストレス負荷の方法としては，Leedham ${ }^{4)}$ の報告に 準じ， $50 \times 60 \times 90 \mathrm{~cm}$ （幅 $\times$ 高さ $\times$ 奥行）の犬舎内での 飼育, 寸なわち体重 $15 \mathrm{~kg}$ 前後のイヌにとって軽度の行 動制限をうける拘禁状態下におく方法らをちいた。ま たストレス負荷の期間は 3 週間とした。

排便回数および便の性状に関する検討

実験犬について全期閒中の排便回数および便の性状を 比較検討した.

消化管運動に関する検討方法

\section{X線学的観察}

$100 \%$ 硫酸 barium $3 \mathrm{ml} / \mathrm{kg}$ 娄半流動飼料（実験動物 用飼料 T2 号オリエンタル䤉母工業 K.K.) $20 \mathrm{~g} / \mathrm{kg}$ に 
よく混じ，barium meal（Ba）を作成，投与した， X 線撮影は，投与後 1 時間毎, 24 時間後まで意識下に施行 した．この方法で無処置群，TV 群においては TV 2 週後, さらにストレス群においてはストレス負荷開始 2 週後における $\mathrm{Ba}$ の消化管内移動の状態，形態の変化， 消化管の收縮運動の状況について検討した.

2. Transducer による慢性植え込み実験

pentobarbital- $\mathrm{Na} 30 \mathrm{mg} / \mathrm{kg}$ を静脈内投与後, 腹部正 中切開で開腹し，伊藤ら ${ }^{6)} に よ り$ 作製された transducer （スターメディカル社製F 121-S）を縫着した。 なお縫 着に先立って atropine $0.1 \mathrm{mg} / \mathrm{kg}$ を静脈内に投与し， 縫着操作に伴う消化管の収縮運動を抑制した. transducer は消化管の輪状筋の収縮波が測定できるように消化 管の横軸方向に漿膜側に縫着した. 縫着部位は胃前庭部 （幽門輪より $3 \mathrm{~cm}$ 口側），近位結腸（回盲弁より $5 \mathrm{~cm}$ 肛門側)，結腸括約部（前結腸動脈肛門側末梢枝と後結 腸動脈口側末梢枝の吻合部) ${ }^{7)}$ ， 遠位結腸（肛門より 20 $\mathrm{cm}$ 口側) の 4 力所とした (Fig. 1). 縫着後導線は腹壁 から皮下を通し後頸部から体外へ引き出し固定した．消 化管運動の測定は手術侵襲の影響から完全に離脱した術 後 2 週間目より開始し，24時間連続的に意識下で行っ た. 以上の方法を用い，無処置群，TV 2 週後およびス トレス負荷開始 2 週後の消化管運動曲線を排便を中心に 比較検討した.

本実験中，固形哴料（DS-2 オリエンタル 酵母工業 K.K.) 約 $20 \mathrm{~g} / \mathrm{kg}$ を 1 日 1 回，一定時刻に投与し，水分

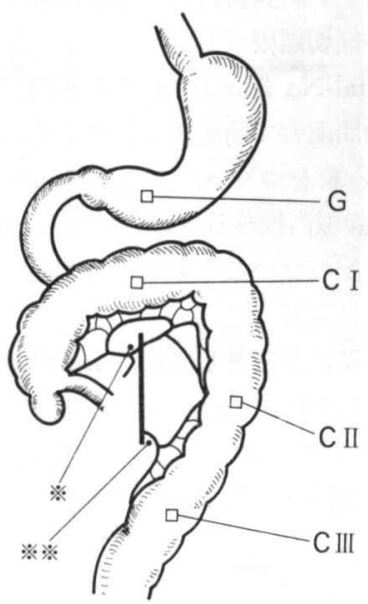

Fig. 1 Schema of recording system by strain gauge force transducer for movement of gastric antrum $(\mathrm{G})$, proximalcolon $(\mathrm{CI})$, colic sphincter (CII) and distal colon (CIII).

* anterior colic artery

** posterior colic artery
は水道水を自由に摂取させた。

\section{II. 実 験 結 果}

排便回数および便の性状に関する検討

\section{1. 無処置群}

$\mathrm{X}$ 線学的観察期間中, 1 日 1 回の固形便排泄が10頭中 8 頭に認められ，水様便排泄は 2 頭に認められた.

transducer による慢性植え込み実験期間中 は全頭に

1 日 1 回の固形便排泄が認められた。

\section{TV 群}

TV 前では 1 日 1 回の固形便排泄が全頭に認められ， $\mathrm{TV}$ 後では 1 日 $2 \sim 3$ 回の水様便排泄が全頭に認められ た.

\section{3. ストレス群}

ストレス負荷前では 1 日 1 回の固形便排泄が全頭に認 められた. しかし，ストレス負荷開始 2 週後では 1 日 2 〜 3 回の水様便排泄が 4 頭に認められ, その他, 便通異 常が認められなかったものは 1 頭であった.

\section{$\mathrm{X}$ 線学的観察}

1. 無処置群

$\mathrm{Ba}$ の消化管内移動の状態, 消化管の収縮運動の状況 の代表的なものを示せばつぎのとおりである.

1) 1 日 1 回の固形便排泄 (Fig. 2)

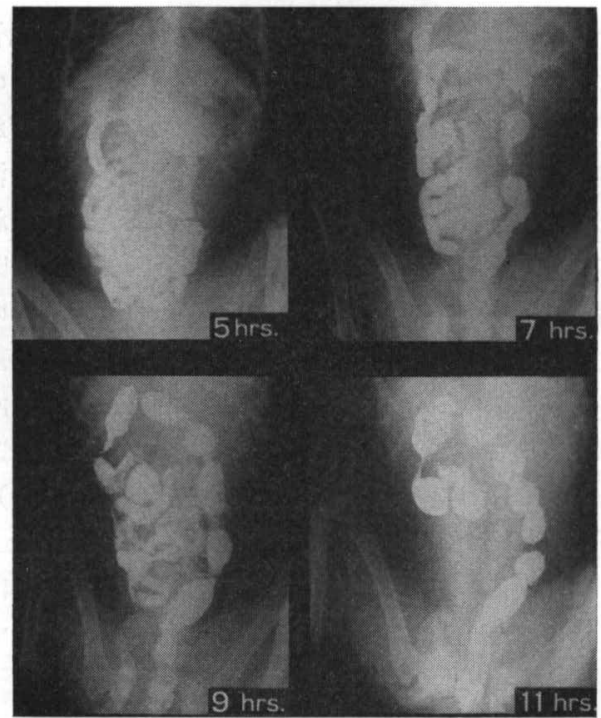

Fig. 2 Time-course changes in barium distribution in digestive tract in normal.

結腸全体に収縮輪が認められ，時間の経過とともに， $\mathrm{Ba}$ の濃縮も進み，糞塊形成が認められた。

2) 水様便排泄 (Fig. 3)

結腸に収縮輪は認められず，結腸は鉛管状となってお 


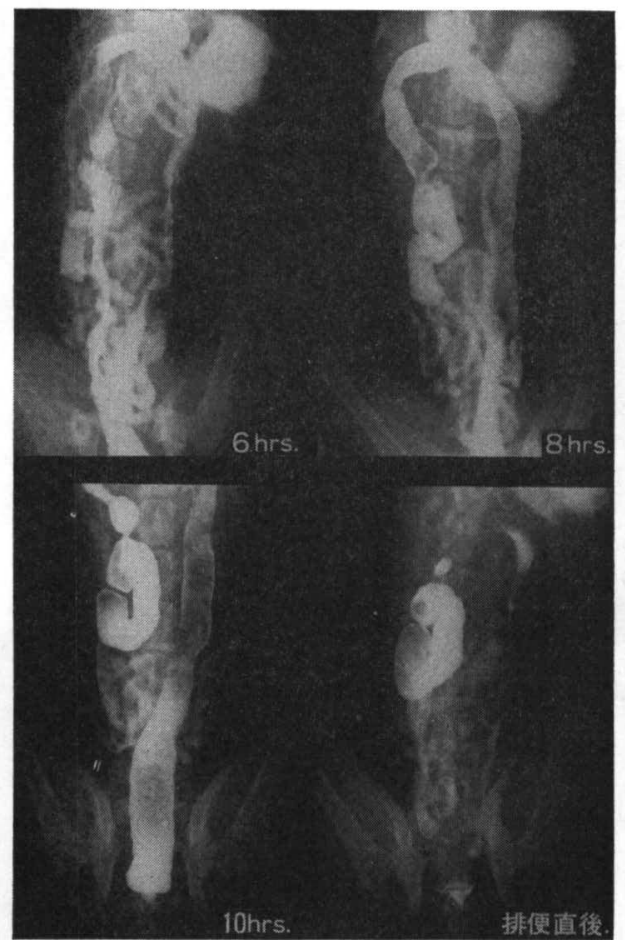

Fig. 3 Time-course changes in barium distribution in digestive tract in diarrhea.

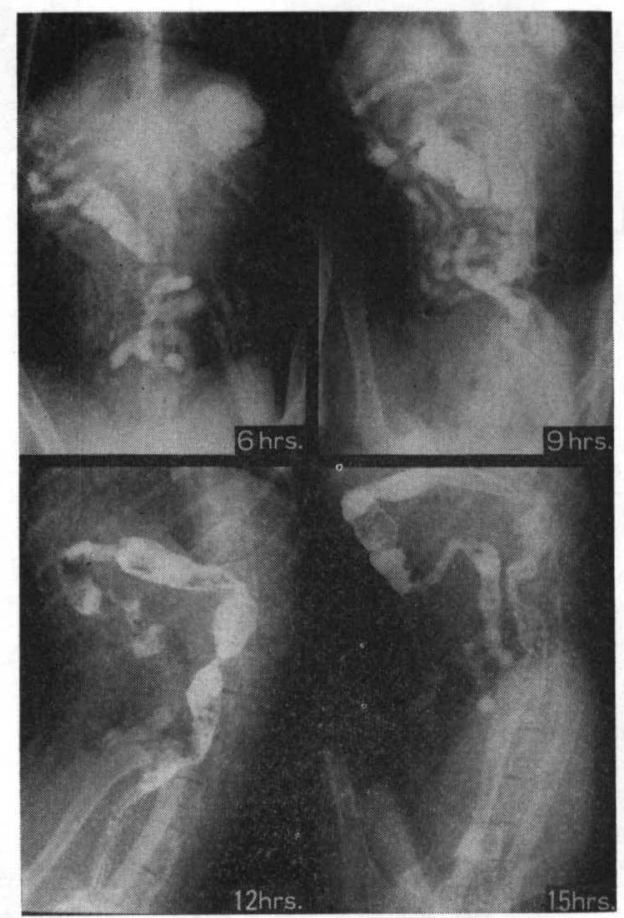

Fig. 4 Time-course changes in barium distribution in digestive tract 2 weeks after TV.

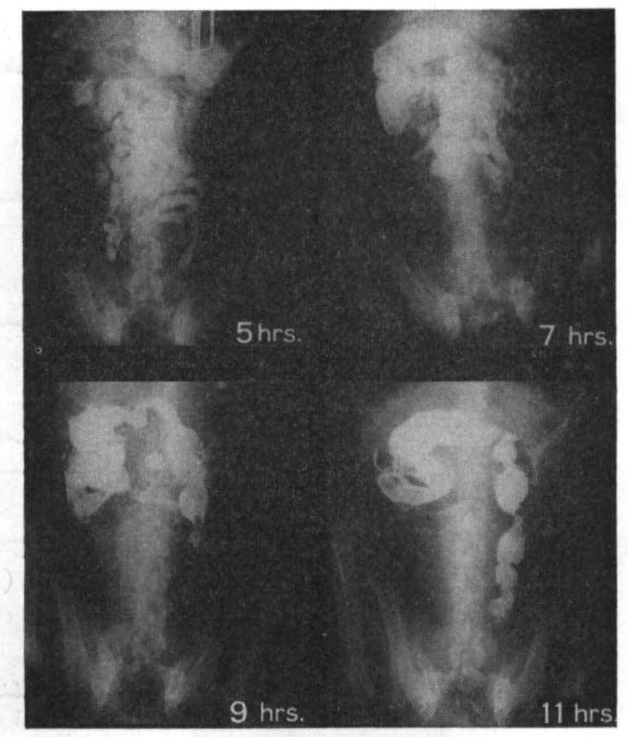

Fig. 5 Time-course changes in barium distribution in digestive tract 2 weeks after loading the stress.

り, $\mathrm{Ba}$ の濃縮も糞塊形成も認められなかった. また排 便により遠位結腸にあった $\mathrm{Ba}$ の消失が認められた.

2. TV 群

$\mathrm{Ba}$ の消化管内移動の状態, 消化管の収縮運動の状況 の代表的なものを示せば Fig. 4 に示すとおりである.

結腸に明らかな収縮輪は認められず, 結腸の一部は鉛 管状となっており, $\mathrm{Ba}$ の濃縮や, 糞塊形成も認められ なかった.

3. ストレス群

水様便排泄が認められた 4 頭の Ba の消化管内移動の 状態, 消化管の収縮運動の状況の代表的なものは Fig. 5 に示すとおりである. 遠位結腸に収縮輪が認められる が，近位結腸においては明らかな収縮輪は認められず鉛 管状となっており, $\mathrm{Ba}$ の濃縮や, 糞塊形成も認められ ず, 近位結腸で大腸運動の低下が認められたものは 2 頭 であった. また近位結腸および遠位結腸で運動の低下が 認められたものは 2 頭であった.

これに反して水様便排泄が認められなかった 1 頭では 遠位結腸のみに運動低下か゚認められた. 以上, X線学的 検討から 3 群の水様便排泄が認められたイ又の大腸運動 に違いは認められなかった.

Transducer による慢性植え込み実験.

1. 無処置群

排便を中心とした消化管運動曲線の代表的なものは Fig. 6 に示すとおりである.

正常便排泄にさきだち結腸に近位結腸より遠位結腸に 伝播する大収縮, いわゆる Karaus ら8)のいう giant 


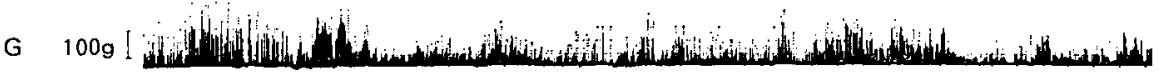

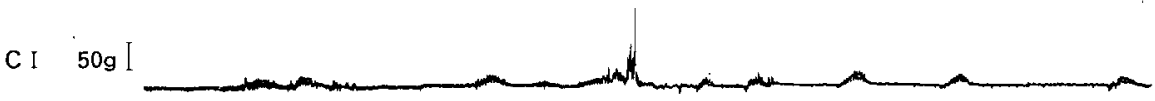

CII $50 \mathrm{~g}$ I

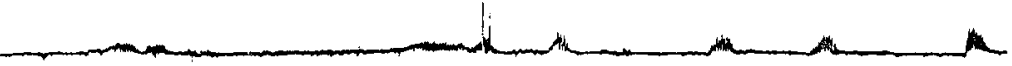

C III $50 \mathrm{~g}$

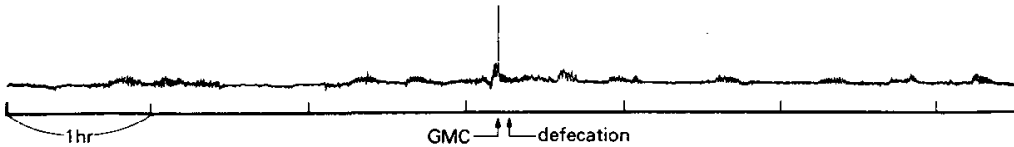

Fig. 6 Contractile patterns of the gastric antrum, proximal colon, colic sphincter, and distal colon in normal. ( $1 \mathrm{~mm} / \mathrm{min}$ )

G $1009 \mathrm{I}$ I

C I $50 \mathrm{~g}$

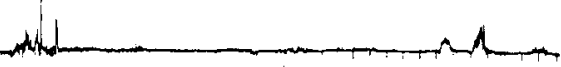

C I $\quad 50 \mathrm{~g}$
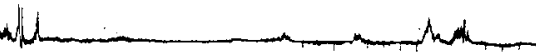

C III $\quad 50 \mathrm{~g}$

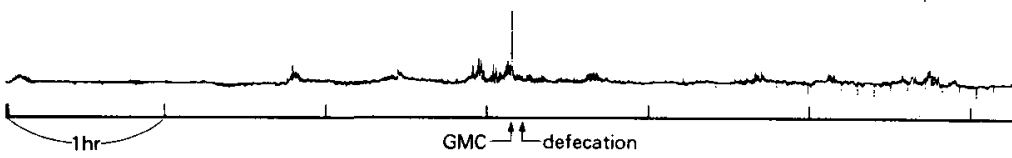

Fig. 7 Contractile patterns of the gastric antrum, proximal colon, colic sphincter and distal colon 2 weeks after TV. $(1 \mathrm{~mm} / \mathrm{min})$

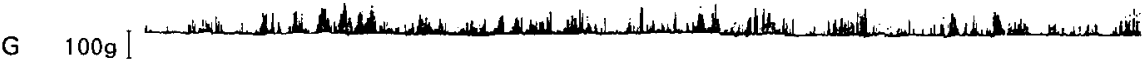

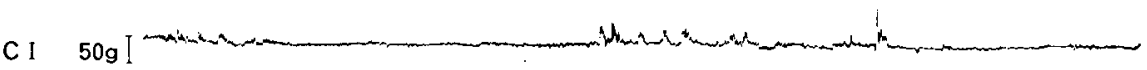

C I

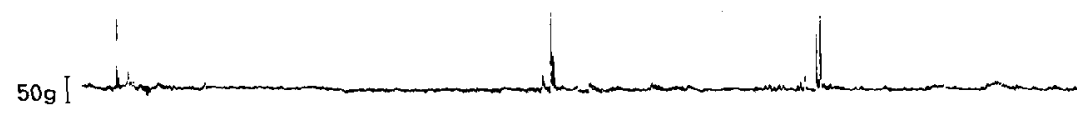

cin

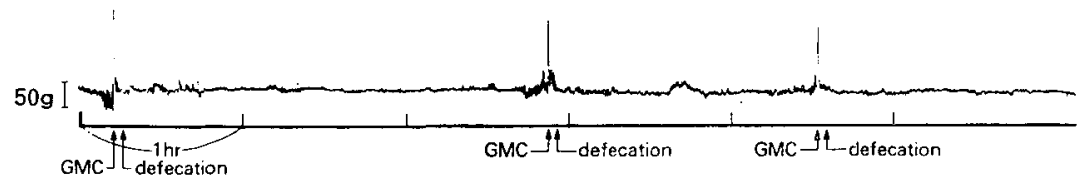

Fig. 8 Contractile patterns of the gastric antrum, proximal colon, colic sphincter and distal colon 2 weeks after lording stress. $(1 \mathrm{~mm} / \mathrm{min})$

migrating contraction(GMC) が認められた。結腸各 部位において排便後に多峰性の収縮波の発生顛度增加 と，個々の波の収縮力增加が認められた。

2. TV 群

排便を中心とした消化管運動曲線の代表的なものは
Fig. 7 に示すと於りである.

GMC が認められ，その直後の排便は水様便であった にもかかわらず，排便後結腸各部位において明らかな多 峰性の収縮波の発生頻度増加と, 個々の波の収縮力增加 はいずれも認められなかった。 
3. ストレス群

水様便排泄が認められた 4 頭の排便を中心とした消化 管運動曲線の代表的なものは Fig. 8 に示すとおりであ る.

GMC が頻回に認められたものでは，その直後の排便 は水様便であった，排便間に执いて結腸各部位に明らか な多峰性の収縮波の出現は認められなかった。

便通異常が認められなかった 1 頭の消化管運動曲線は 無処置群上同様のものであった.

以上，排便を中心とした消化管運動曲線の検討からも 水様便排泄が認められたイヌの大腸運動に違いは認めら れなかった。

\section{III. 考 察}

下疬とは一般的に液状または，それに近い状態の糞便 が排泄されることをいい，その回数は問わないと理解さ れている．また下痢では消化管とくに大腸の運動が立進 していると漠然と思われてきた。しかしながら大腸運動 には非推進性の分節運動と大腸内容の移送を行う運動で 自律神経の作用をうける総蝡動および逆蠕動があり，個 々の運動に分けて下痢の際の大腸運動の十分な解明が成 されているわけではない。

過敏性腸症候群（IBS）に代表されるようにストレス により下麻が生じることは一般的によく知られている事 実である．また臨床上 TVにともなう術後機能障害の 重要な症状の 1 つに下浰がある9,10)。今回これらの動物 実験モデルをもちい，下浰の際の大腸運動の検討を行っ $た^{5,11)}$.

X線学的検討において，分節運動をあらわしていると 考えられる収縮輪の減少，もしくは消失㧍よび結腸の鉛 管状化が，水様便排泄がみられたイヌのすべてに認めら れた。すなわち下痢の際の分節運動は，六進ではなくむ しろ低下していることを示している．またこのことがす べての水様便排泄がみられたイヌに認められたことよ り，たとえ原因は何であれ，分節運動の低下という点に おいては本質的な違いはないと考えられる。

下䖉が認められた際のX線写真を詳しく検討すると， 結腸に収縮輪は誌められず，結腸は鉛管状となってお り， $\mathrm{Ba}$ の㴽縮む，粪塊形成も認められなかった。また 排泄により遠位結腸の $\mathrm{Ba}$ が消失していた。すなわち, 遠位結腸の固形化されない腸内容が総蠕動でいっきに肛 門に運ばれ排泄されたと理解できる。

吉田ら 12-14) は大腸に打ける水および電解質の吸収, 分 泌は大腸全体を均一に行われているものではなく，大腸 を分節的に灌流した結果では，水拉よび電解質の吸収能 は近位結腸の方が遠位結腸よりも大きいと述べている。
中嶋(1)によれば，TVにより大腸の多峰性の収縮波の持 続時間は大腸各部位で有意に短縮したが，振幅の減弱は 遠位結腸より近位結腸の方が著明であり，これは大腸に おける迷走神経支配のためではないかと述べている．ま た水様便排泄が認められたものは，ストレス群において 近位結腸および遠位結腸，もしくは近位結腸のみに分節 連動の低下が譛められた．水样便排泄が認められなかっ たものは遠位結腸しか分節運動の低下が認められなかっ た.

これらのことより，下痢は種々の原因により水・電解 質の吸收能の高い近位結腸を中心に吸収・分泌能の破綻 と同時に分節運動の低下がおこり，このため腸内容物が 固形化されず，総蠕動でいっきに肛門に運ばれ排泄され るものであると考えられる。

最近，上部消化管運動の解析に関しては，食物摄取を 境とした digestive state と interdigestive state に分 けて検討されるようになってきた ${ }^{15,16)}$.これは食物摂取 により胃を中心とした上部消化管運動のパターンが一変 するためである。すなわち今まで空虚であった胃の中に 食物が入ってきたためによる変化と理解できる．大腸運 動を検討するとき，大腸にとって胃における食物捸取に 相当するものは排便であると洘えられる，才なわち，排 便により淔腸，結腸内の糞便が排泄され，これが大腸運 動パターンになんらかの変化を及ぼしているのではない

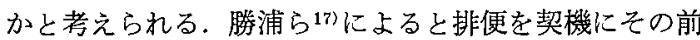
後において大腸運動のパターンは著明に変化しており， 排便を中心にその前後における運動パターンを検討する のが妥当であると述べている. 今回これに従い transducerをもちい排便を中心に下桨際における大腸運動 パターンを検討した。

Karaus ら ${ }^{8)}$ は transducer を用い意識下イヌの排便時 結腸運動を観察検討し，排便に先立って上部結腸に発生 し下部に伝播する大収縮波を GMC および，この GMC が下部結腸に達する值前または到達したときに排便が起 こることから，GMC がいわゆる総蠕動に相当し排便の 際には結腸内容物排泄の主たる力になっていると述べて いる。

TV 群における下痢の際の運動曲線（Fig. 7) を検討 すると，GMC の直後に下痢便排泄が認められたが，排 便後に結腸各部位において正常便排泄後のような多峰性 収縮波の出現は認められなかった。ほた，排便からつぎ の排便の閒にストレス群（Fig. 8) においても結腸各部 位に正常便排泄後のような多峰性収縮波の出現は認めら れなかった.このことはX線学的検討の結果と同じよう に，下浰の際の分節運動は，光進ではなくむしろ低下し ていることを示している。すなわら運動曲線の面から下 
峲をみると種々の理由により粪塊形成に至らなかった腸 内容物が GMC により一気に肛門より排泄され，排便 後も分節運動の回復はなく依然分節運動の低下が存続す るものと思われる.従来よりいわれている下浰の際の大 腸運動㝋進はこの頻回の GMC をとらえていたのでは ないかと考えられる。

Wingate ${ }^{18)}$ は，腸管運動は腸管神経叢 (enteric nervous system：ENS）により制御されているが，この ENS と中枢神経系 (central nervous system : CNS) との間には CNS-ENS link とよばれる密接な関係が存 在し，腸管運動に対し㥵互に影響を及ぼし合っていると 述べている.一方，ストレスが CNS を介して ENS に影響を与え腸管運動に影響を及ぼすことも明らかにさ れている5,19-22). また松枝ら ${ }^{23)}$ は IBS はこの CNSENS linkに破綻が生し腹痛の閾值が低下している状態 にあるのではないかと述べている。

以上のことより下剆は，ストレスなどの種々の原因に より ENS, CNS, CNS-ENS link 破綻を生じこのため 正常の大腸分節運動は低下, 同時に GMC 発生の閾值 む低下している状態にあると考えられる。 そして，その 結果 GMC の発生頻回が増加し下淑が引き起こされる. すなわち下痳の際の腸管は hypokinetic ではあるが, 一方では hypersensitive で hyrreactive な状態にある と考えられる.

\section{IV. 結 語}

実験的に下浰が認められる動物実験モデルをもちいて 種々の下浰に㧍ける大腸運動を記録，検討し以下のこと がわかった.

1）下涠をきたしたすべての対象において大腸の分節 運動の低下が認められた.

2）下瘚をきたしたすべての対象において頻回の GMC が認められた.

\section{文献}

1）鈴木裕一, 日向正義：分泌性下剻. 星猛, 藤田 道也編. 新生理学体系。第18卷消化と吸收の生 理学. 東京, 医学書院, 1988, p 315-324

2）石川筬，滈橋恒男：下淑。臨床上研究 60 : $1128-1133,1983$

3) Edward F, James WF : Antidiarrheal agents and laxatives. Clin Gastroenterol $8: 164$, 1979

4) Leedham C: Care of the Dog. New York, Scribner's Sons, 1961, p 243

5）落合匠：ストレスの大腸に及ぼす影響に関す 万実験的検楌。目消病会誌 $87: 965-972 ， 1990$

6) 伊藤 㘈：Extraluminal strain gauge force transducer の作製と慢性植え达み。日平滑等誌
$13: 33-43,1977$

7）桝田龟次郎：大腸の運動, 日本生理誌 $2: 196-$ 212, 1937

8) Karaus M, Sarna SK : Gaintmigrating contractions during defecation in the dog colon. Gastroenterology 92 : 925-933, 1987

9) Collons $\mathrm{CD}$ : Lomotil in treatment of postvagotomy dia-rhea. $\mathrm{Br}$ Med J $2: 560-561$, 1966

10) Johnston D, Humphrey CS, Walker BE, et al: Vagotomy without diarrhea. Br Med J $3: 788-790,1972$

11）中嶋䓔司：迷走神経の大腸運動への関与に関す る実験的研究. 日本大腸肛門病会誌 $43: 1-8$, 1990

12）吉田豊，佐タ木大輔：大腸の機能と病態。臨 朱と研究 $67: 3688-3694,1987$

13) Billich $C D$, Levitan $R$ : Effects of sodium concentration and osomlality on water and electrolyte absorption from the intact colon. $\mathrm{J}$ Clin Invest $48^{\circ}: 1336-1346,1969$

14) Fukuda $S$, Kato $H$, Sano $M$, et al: Investigation of regional differences in water and electrolyte absorption across the human colon by in vivo perfusion method. Jpn J Med $25: 162-166,1986$

15) Itoh A, Aizawa I, Sekiguchi $T$ : The Interdigestive migrating complex and its significance in man. Clin Gastroentrol $11: 497-$ 521,1982

16) Szurzewski JH: A migrating electric complex of the canine small intestine. Am J Phy. siol $217: 1757-1763,1969$

17）勝浦康光，長留 徵，落合匠ほか：排便を中 心とした大腸運動のパターン分類にっいて。日 平滑筋誌 $26: 259-261,1991$

18) Wingate DL: The CNS-ENS link. Motility $2: 7-10,1988$

19) McRae $S$, Younger $K$, Thompson DG, et al: Sustained mental stress alters human jejunal motor activity. Gut $23: 404-409$, 1982

20) Thompson DG, Richelson E, Malagelada J$R$ : Perturbation of upper gastrointestinal function by cold stress. Gut $24: 277-283$, 1983

21) Kumar D, Wingate DL: The irritablebowel syndrome: a paroxysmal motor disor. der. Lancet ii : 973-977, 1985

22) Valori RM, Kumar D, Wingate DL: Effects of different types of stress and of "proki. netic" drugs on the control of the fasting motor complex in humans. Gastroenterology $90: 1890-1900,1986$

23）松枝 啓，梅田典嗣：過敏性腸症候群の病型分 類一背景因子とその特異性にっいて一，三好秋 馬編, 過敏性腸症候群の落断之治療, 東京, 医 薬ジャーナル社, 1989, p 34-51 


\title{
The Motility of Colon in Diarrhea in the Dog
}

\author{
T. Ochiai, A. Nagahama and N. Sakakibara \\ The First Department of Surgery, Juntendo \\ University, School of Medicine, Tokyo
}

The following experiment has been made to clarify the motility of the large intestine in diarrhea by the use of adult morgrel dogs as subject.

The following results have been obtained by recording and assessing the motility of the intestine by roentgenograpy with time and by the use of a strain gauge force transducer regarding the motility of the large intestine in which diarrhea of various types in experimental animal models in which diarrhea was observed experimentally, entire shaft vagotomy and loading of restraint stress.

Decrease of the normal motility of the large intesinal segment was observedin diarrhea, but giant migrating contraction (GMC) was seen frequently. This was the phenomenon observed in all the subjects which developed diarrhea regardless of its cause.

It was suggested that the large intestinal motility in diarrhea which is pointed out conventinally had frequent occurrences of GMC. The intestine in diarrhea is hypokinetic, but it was considered, on the other hand, that the organ is in hypersensitive and hyperreactive states by which GMC occurs frequently. 